\title{
Fuzzy Logic Controller Application for an Active Two-Axis Solar Tracking System
}

\author{
Chairul Imron ${ }^{1}$, Imam Abadi ${ }^{2, *}$, Nurika Brillianti ${ }^{2}$, Muhammad Khamim Asy'ari ${ }^{2}$ \\ Yusilawati Ahmad Nor ${ }^{3}$, and Aep Saepul Uyun ${ }^{4}$ \\ ${ }^{1}$ Department of Mathematics, Institut Teknologi Sepuluh Nopember, Jl. Teknik Kimia, Sukolilo, \\ Surabaya 60111, East Java, Indonesia. \\ ${ }^{2}$ Department of Engineering Physisc, Institut Teknologi Sepuluh Nopember, Jl. Teknik Kimia, \\ Sukolilo, Surabaya 60111, East Java, Indonesia \\ ${ }^{3}$ Department of Biochemical-Biotechnology Engineering, Kuliyyah of Engineering \\ International Islamic University Malaysia (IIUM), Jl. Gombak, 53100, Selangor, Malaysia \\ ${ }^{4}$ Graduate School of Renewable Energy, Darma Persada University, Jl. Taman Malaka \\ Selatan No. 22, Pondok Kelapa, East Jakarta 13450, Indonesia
}

\begin{abstract}
The changes in the intensity of solar radiation cause the electrical power produced by solar panels to be not optimal. The solar panel position control system to the position of the solar is an effort to overcome this problem. There are four Light Dependent Resistor (LDR) sensors placed on the sides of the four cardinal directions. The difference in the intensity of solar radiation received by each sensor causes the position of the solar panel to turn perpendicular to the position of the solar. The control method used is fuzzy logic control with three membership functions. The controlled variables are pitch angle and yaw angle in an active two-axis solar tracking system. Input fuzzy logic control is an error, and output is PWM. The results of the performance of the pitch angle control system produce settling time for $10 \mathrm{~s}$ and error steady-state obtained by $0.080 \%$, while for the yaw angle control system produces settling time for $13 \mathrm{~s}$ and steady-state error is obtained at $0.038 \%$. The existence of a control system resulted in an increase in the percentage of power above $30 \%$ with a power difference of $7.49 \mathrm{~W}$ to a fixed panel.
\end{abstract}

Keywords: Light-dependent resistor, pitch angle, renewable energy, solar energy, yaw angle

\section{Introduction}

The daily and seasonal solar radiation are essential issues in the utilization of solar energy. The amount of radiation that is obtained by the area of the solar panels is equivalent to the power of electricity generated [1]. The direct usage of solar energy faces a major constrain, namely the limited time when the solar emits massive radiation so its function could not be continued. Therefore, the use of solar energy has limitations, impracticability, and low

\footnotetext{
*Corresponding author: imamabadi02@gmail.com
} 
efficiency. While, there are some problems that occurred, several researchers have studied the effectiveness of practical methods of solar energy. The first method called solar tracking system, which the direction of solar panels will change due to the solar radiation position [2-5]. The purpose of this method is to optimize the electrical power received by solar panels when capturing solar radiation by controlling the position of the solar panel against the position of the solar automatically.

Solar panels are devices that function to convert solar energy into electrical energy. Solar panels are influenced by solar radiation and temperature on the surface of solar panels. The changes in solar position every time is affecting the solar radiation received by the solar panel, so it generates a fluctuated energy. The amount of current produced by solar panels equals the magnitude of the illumination of the incoming solar. The magnitude of the exposure to solar radiation changes according to the position of the solar and the weather. Weather types such as cloudy weather and solar weather affect large amounts of solar radiation.

The research with the theme of solar tracking system in 2010 has been carried out with the title of application of fuzzy logic control on the solar active tracking system using single-axis solar panels using LDR sensors but only examining the one-panel position and not comparing the obtained power efficiency $[6,7]$. In the following year, two studies were conducted; namely, the first study of the design of Arduino Mega 2560-based single-axis solar tracking system using PID control to obtain a maximum overshoot of $3.85 \%$, settling time of $58 \mathrm{~s}$, rise time of $37 \mathrm{~s}$ and steady-state error of $1.1 \%$ [8]. The second research designed of the solar tracking system using PID control on the azimuth axis. This study used two-panel positions with the following results: settling time of $59.5 \mathrm{~s}$, rise time of 33.799 s. However, the response experienced continuous oscillation until finally, it reaches a steady-state [9].

In order to develop solar tracking from the researches that have been carried out, it is necessary to apply an active two-axis solar tracking prototype that moves with pitch and yaw position with fuzzy logic control method to control the position of solar panels based on the intense solar radiation received by the first LDR sensor (setpoint) and the second LDR (measurement variable). Between the two sensors installed a barrier (balancer) so that if the solar panel does not face perpendicular to the position of the solar, there will be an intense solar radiation difference that will be received by each sensor. The results of the development of solar tracking from previous studies are expected to have a better system performance index with a value of rising time, settling time, maximum overshoot, and steady-state error smaller than previous studies [10-12]. This research offers control techniques using fuzzy logic by using two forms of input membership functions that are owned by fuzzy (triangles and trapezoidal) with three membership functions for input and output fuzzy logic control.

\section{Solar tracking system}

The solar tracking system is a series of systems that utilize solar panels by capturing the intensity of solar lighting so that it can produce optimal electric power. Prototype solar tracking system that has been designed consists of LDR as a sensor, microcontroller ATMEGA 16 as a controller, fuzzy logic control as a control method, DC motor as an actuator, and solar panels as a plan. Changes in the angle of the DC motor function to move the position of the solar panel to the position of the sun automatically so that the crosssection is always perpendicular to the direction of the incoming solar radiation. The prototype solar tracking is designed with two positions for pitch and yaw control.

Light Dependent Resistor (LDR) is one type of light sensor. The LDR sensor functions as a sensor for the intensity of solar radiation. The comparison between the two LDR 
sensors is defined as an error and will send a signal to the controller so that the controller will control the angular position of the DC motor. The angular position of the DC motor will move the solar panel perpendicular to the position of the sun. The LDR sensor produces a resistance as output by inputting the intensity of solar radiation.

\section{Methods}

An active two-axis solar tracking control system consists of several components. The components include sensors, controllers, actuators, and plans. The sensors used are four LDR (pitch and yaw), controller component is ATMEGA16 microcontroller with the fuzzy logic method, actuators are two DC motors, and the plan is solar panels. The block diagram of the solar tracking control system for pitch and yaw control is shown in Figure 1 and Figure 2.

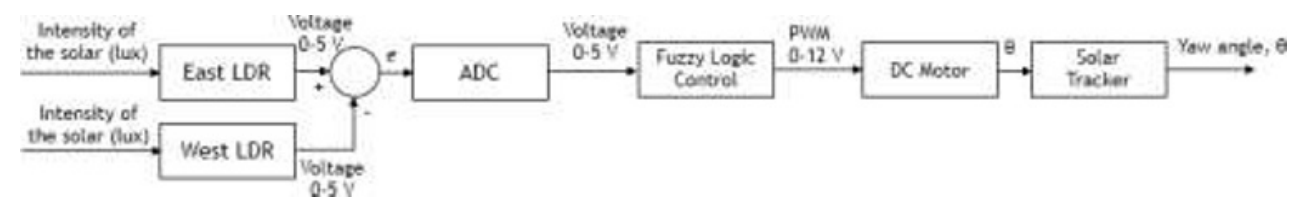

Fig. 1. Solar tracking block diagram for pitch control

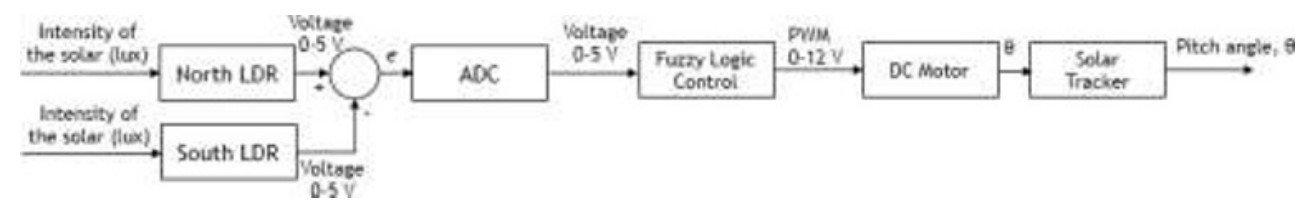

Fig. 2. Solar tracking block diagram for yaw control

The control variables for a two-axis active solar tracker system are pitch and yaw angle. The setpoint is the value of the intensity of solar radiation regarding the north LDR for pitch control and the east LDR for yaw control. Error is the difference in the value of the north LDR voltage to the south LDR for pitch control or the difference in the east LDR to the west LDR for yaw control. The control signal is a PWM value, and the manipulation variable is the angle position $(\theta)$ of the DC motor. The changes in the angular position of the DC motor cause changes in the position of the solar panel.

\subsection{Design of fuzzy logic control}

This Fuzzy logic control design uses three input and output membership functions in the form of input membership functions are triangles and trapezoid. The fuzzy logic reasoning method is Sugeno because the output of the sun's active tracking system is a constant in the form of decimal values OCR1A (pitch) and OCR1B (yaw) on ATMega 16, which represents variations in voltage values applied to DC motors.

Fuzzification is the process of mapping crisp input values into a degree of membership. Crisp input is an LDR voltage error. Voltage errors are defined as the difference between the north LDR output voltage and the south LDR for pitch control or the east LDR output voltage with west LDR for yaw control. The fuzzy logic control input has three membership functions, namely negative, zero, and positive, and the output section has three membership functions, namely CounterClockWise, STOP, and ClockWise. The fuzzy logic control membership function for pitch and yaw controls is shown in Figure 3 and Figure 4. 


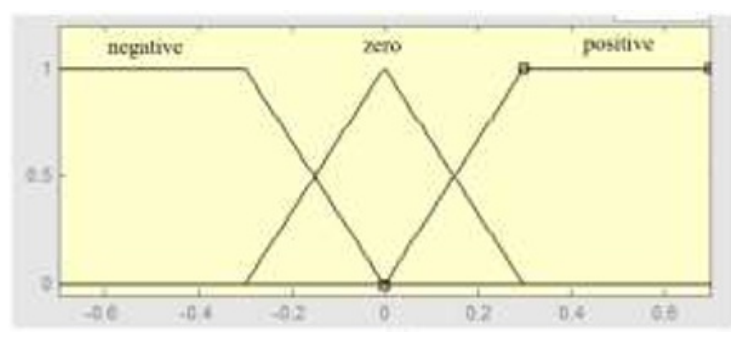

(a)

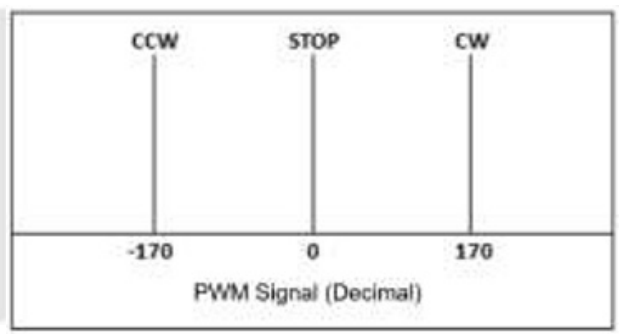

(b)

Fig. 3. Membership function of (a) input (b) output fuzzy logic control for pitch control.

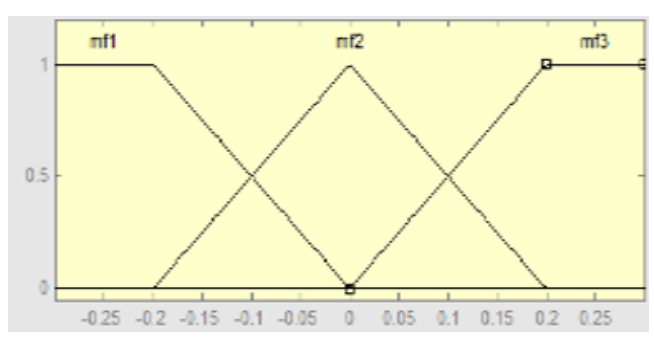

(a)

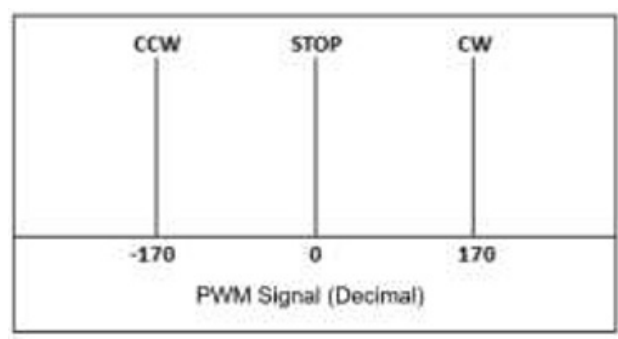

(b)

Fig. 4. Membership function of (a) input (b) output fuzzy logic control for yaw control.

The fuzzy logic control base rule consists of three rules. The degree of zero membership in the error causes the position of the solar panel facing solar and the DC motor to stop. The degree of positive membership will move the DC motor rotating ClockWise and the degree of negative membership will move the DC motor rotating CounterClockWise. The fuzzy logic control base rule is shown in Table 1.

Table 1. Rule base fuzzy logic control

\begin{tabular}{|c|c|c|}
\hline $\begin{array}{c}\text { Input } \\
\text { (Voltage error of LDR) }\end{array}$ & $\begin{array}{c}\text { Output } \\
\text { (Velocity of DC motor) }\end{array}$ & Note \\
\hline Negative & $\mathrm{CCW}$ & \multirow{3}{*}{$\begin{array}{l}\text { CCW:Counter Clock Wise } \\
\text { CW:ClockWise }\end{array}$} \\
\hline Zero & STOP & \\
\hline Positive & $\mathrm{CW}$ & \\
\hline
\end{tabular}

\section{Results}

\subsection{Set point test response for pitch and yaw angle}

The pitch and yaw response will be known by conducting a set point test. The set point testing is done to determine the time required for the pitch and yaw angle to reach the set point until it reaches a steady state. 


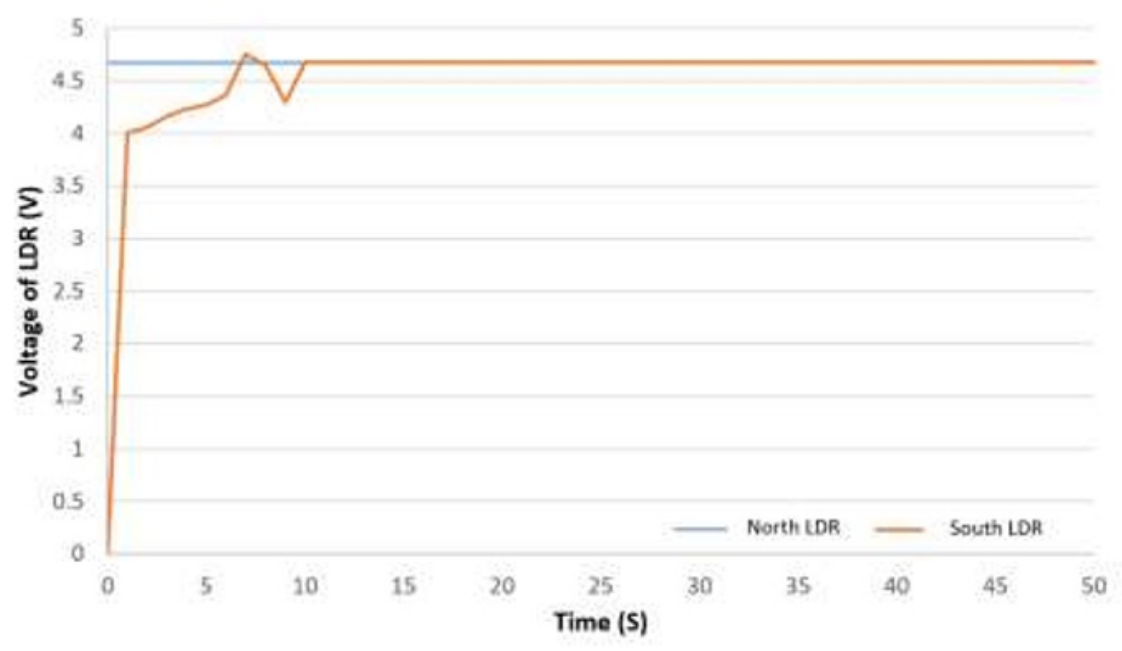

(a)

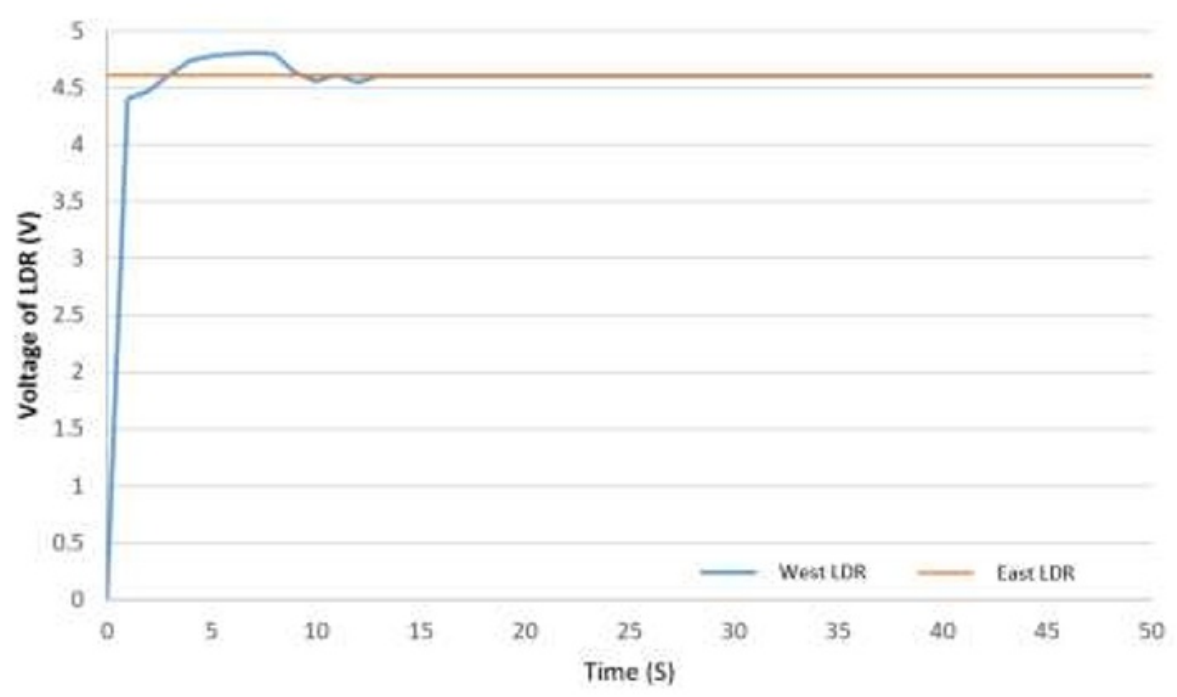

(b)

Fig. 5. Graph of set point test for (a) pitch angles and (b) yaw angle

Figure 5 (a) shows the maximum deviation occurring at the LDR voltage of $4.72 \mathrm{~V}$, with a setpoint value of $4.36 \mathrm{~V}$, the maximum overshoot value observed is $0.080 \%$ against the set point. Rise time is $7 \mathrm{~s}$, and the settling time is $10 \mathrm{~s}$. Steady-state error is obtained at $0.080 \%$.

Figure 5 (b) shows the results of the yaw angle response. The maximum deviation of the setpoint value of the yaw angle occurs at 4.8 LDR voltage with a setpoint value of $4.39 \mathrm{~V}$. The maximum overshoot is generated $0.081 \%$ against the set point. The rise time of $3 \mathrm{~s}$, and settling time for $13 \mathrm{~s}$. The steady-state error was obtained at $0.038 \%$. 


\subsection{Tracking set point test response for pitch and yaw angle}

The tracking setpoint test for pitch and yaw angles is done in front of the ITS (Institut Teknologi Sepuluh Nopember, Surabaya, Indonesia) library on June 12, 2015. The data collection starts at 07:30 until 17:00 with a sampling time of $30 \mathrm{~min}$. The setpoint tracking test is used to determine the control system capable of following changes in setpoint during tracking time $(9.5 \mathrm{~h})$ by looking at the north LDR response to the south LDR for pitch control and the west LDR response to the east LDR for yaw control. The tracking test can also determine the difference in photovoltaic tracking power with fixed photovoltaic power.

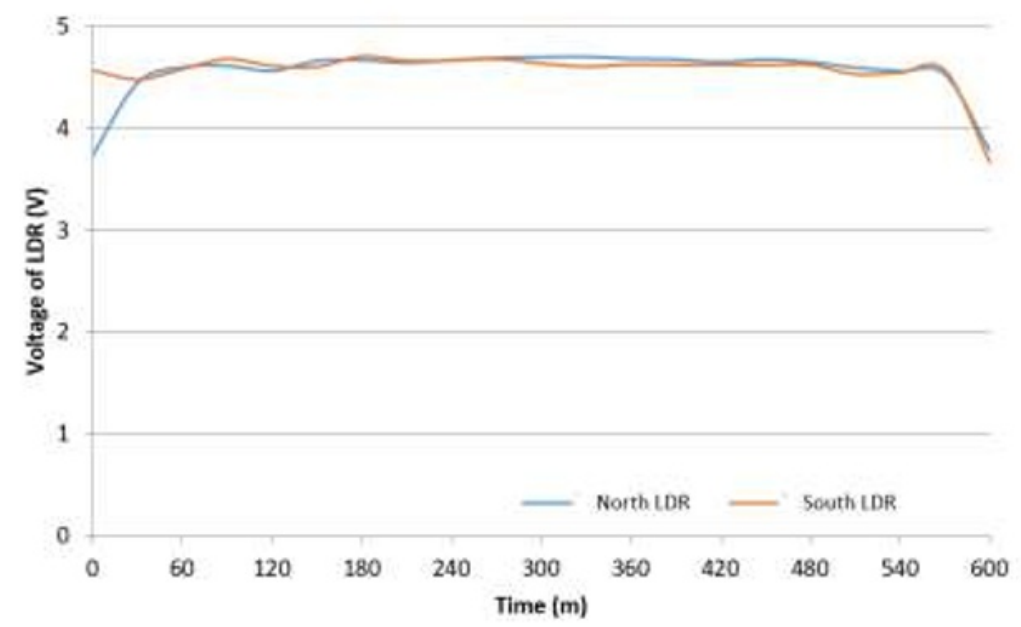

(a)

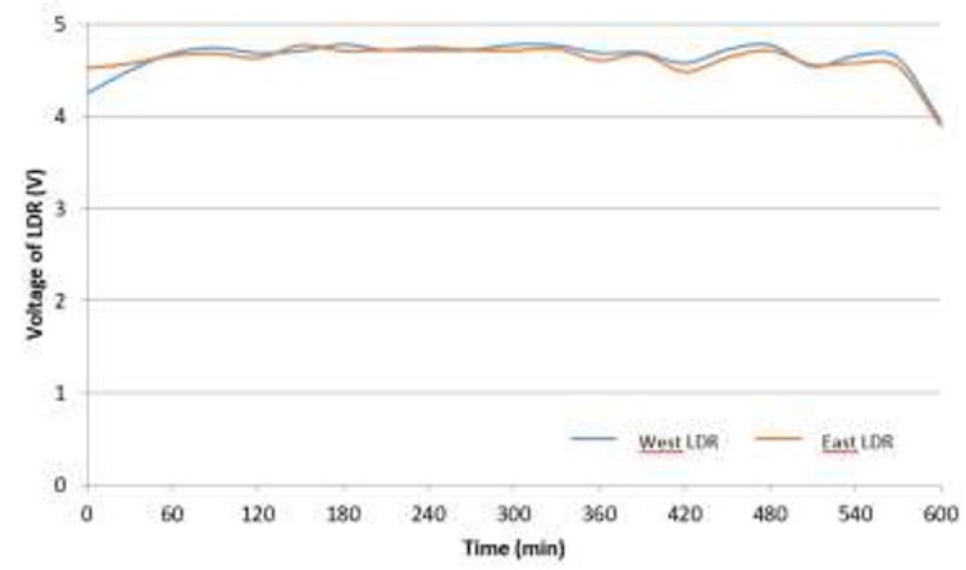

(b)

Fig. 6. Graph of tracking setpoint test for (a) pitch angle and (b) yaw angle

Figure 6 shows that the control system that has been applied causes measurement variables to be able to follow changes in setpoints. It can be seen from the south LDR response to the north LDR for pitch control and the east LDR response to the west LDR for yaw control. 


\subsection{The angular changes against time}

The angular change data is observed every $30 \mathrm{~min}$. The tests are carried out at 07:00 until 16:30. The angular change data is used to determine changes in pitch and yaw angle when tracking is performed. The results of the angular change data are shown in Table 2.

Table 2. Data changes nah in pitch and yaw angles

\begin{tabular}{|c|c|c|c|c|c|c|c|}
\hline \multirow{2}{*}{ No } & \multirow{2}{*}{ Time } & \multicolumn{2}{|c|}{ Angle } & \multirow{2}{*}{ No } & \multirow{2}{*}{ Time } & \multicolumn{2}{|c|}{ Angle } \\
\hline & & $\operatorname{Pitch}\left({ }^{0}\right)$ & Yaw $\left({ }^{0}\right)$ & & & Pitch $\left(^{0}\right)$ & $\operatorname{Yaw}\left({ }^{0}\right)$ \\
\hline 1 & 07:00 & 17.670 & 62.820 & 11 & $12: 00$ & 58.225 & 343.540 \\
\hline 2 & $07: 30$ & 24.241 & 60.512 & 12 & $12: 30$ & 55.758 & 333.147 \\
\hline 3 & 08:00 & 30.411 & 57.682 & 13 & 13:00 & 52.431 & 324.708 \\
\hline 4 & $08: 30$ & 36.784 & 53.811 & 14 & $13: 30$ & 47.834 & 317.018 \\
\hline 5 & 09:00 & 42.464 & 49.137 & 15 & $14: 00$ & 42.110 & 310.530 \\
\hline 6 & 09:30 & 47.672 & 43.203 & 16 & $14: 30$ & 36.270 & 305.830 \\
\hline 7 & 10:00 & 52.273 & 35.616 & 17 & $15: 00$ & 30.100 & 302.150 \\
\hline 8 & $10: 30$ & 56.308 & 25.017 & 18 & $15: 30$ & 23.773 & 299.303 \\
\hline 9 & 11:00 & 58.705 & 13.273 & 19 & $16: 00$ & 17.242 & 297.045 \\
\hline 10 & $11: 30$ & 59.565 & 0.337 & 20 & $16: 30$ & 10.791 & 295.330 \\
\hline
\end{tabular}

\subsection{Electrical power of solar panels fixed and tracking conditions}

The test is conducted to determine the electrical power produced by photovoltaic for 3 d, on June 12, 2015, June, 24 2015, June, 26 2015. The results of the observations are shown in Table 3, which can show a large increase in panel power obtained on an active two-axis solar tracking system.

Table 3. Data on solar panel power increase

\begin{tabular}{|l|c|c|c|}
\hline \multicolumn{1}{|c|}{ Test Place } & Test Date & $\begin{array}{c}\text { Increased Power } \\
\text { Solar Panel (W) }\end{array}$ & $\begin{array}{c}\text { Increased Power } \\
\text { Solar Panel (\%) }\end{array}$ \\
\hline ITS Front Field Library & June 12, 2015 & 8.88 & 36.81 \\
\hline ITS Front Field Library & June 24, 2015 & 8.09 & 41.31 \\
\hline ITS Front Field Library & June, 26 2015 & 5.79 & 31.11 \\
\hline Average & 7.49 & 36.63 \\
\hline
\end{tabular}

Table 3 shows that the magnitude of the percentage increase in power obtained on the active two-axis solar tracking is above $30 \%$ with the difference in tracking panel and fixed panel power of $7.49 \mathrm{~W}$. 


\section{Conclusions}

The results of the performance of the pitch angle control system produce a maximum overshoot of $0.080 \%$, the rise time of $7 \mathrm{~s}$, settling time for $10 \mathrm{~s}$, and error steady-state obtained by $0.080 \%$. Meanwhile for the yaw angle control system produces a maximum overshoot of $0.081 \%$, the rise time of $3 \mathrm{~s}$, settling time for $13 \mathrm{~s}$. Also, the steady-state error is obtained at $0.038 \%$. The percentage increase in power obtained in an active two-axis solar tracking system is by applying fuzzy control logic is above $30 \%$ with a difference in the tracking panel and fixed panel power of $7.49 \mathrm{~W}$. The power efficiency in the active two-axis solar tracking system is $36.63 \%$ on average every $3 \mathrm{~d}$ of testing.

\section{References}

1. M.A. Usta, Ö. Akyazi, İ.H. Altaş, Design and performance of solar tracking system with fuzzy logic controller used different membership functions. 7th International Conference on Electrical and Electronics Engineering (ELECO), (Bursa, Turkey, 2011), pp. II-381. https://ieeexplore.ieee.org/abstract/document/6140202/

2. I. Abadi, A. Soeprijanto, A. Musyafa, A. Design of single axis solar tracking system at photovoltaic panel using fuzzy logic controller. 5th Brunei International Conference on Engineering and Technology (BICET 2014). (Bandar Seri Begawan, Brunei). IET Conference Proceedings, 2014, https://digital-library.theiet.org/content/conferences/10.1049/cp.2014.1086

3. H.-C. Lu, T.-L. Shih, Fuzzy system control design with application to solar panel active dual-axis sun tracker system, IEEE International Conference on System, Man and Cybernetics., pp. 1878-1883, 2010.

https://ieeexplore.ieee.org/document/5642275

4. G. Ozuna, C. Anaya, D. Figueroa, N. Pitalua, Solar tracker of two degrees of freedom for photovoltaic solar cell using fuzzy logic, The World Congress of Engineering 2011, (London, UK, 2011), pp. 1-4.

https://www.researchgate.net/publication/276278657_Solar_Tracker_of_Two_Degre es_of_Freedom_for_Photovoltaic_Solar_Cell_Using_Fuzzy_Logic

5. W. Luo, Y. Wu, A servo system of tracking automatically for solar cell based on fuzzy controller, 2010 International Conference on Management and Service Science, (Wuhan, China, 2010), pp. 1-4. https://ieeexplore.ieee.org/document/5578527

6. C.H.A.H.B. Baskoro, Aplikasi kendali logika fuzzy (KLF) pada sistem tracking aktif matahari tipe single axis panel surya. [Application of fuzzy logic controller FLC in active sun tracking system single type-axis solar panel]. [Undergraduate Thesis]. Teknik Fisika, Institut Teknologi Sepuluh Nopember, Surabaya, Indonesia (2010). [in Bahasa Indonesia]. p. 105. http://digilib.its.ac.id/ITS-Undergraduate$\underline{3100011041816 / 13764}$

7. I. Abadi, A. Soeprijanto, A. Musyafa, A. Design of single axis solar tracking system at photovoltaic panel using fuzzy logic controller. 5th Brunei International Conference on Engineering and Technology (BICET 2014). (Bandar Seri Begawan, Brunei). IET Conference Proceedings, 2014, https://digital-library.theiet.org/content/conferences/10.1049/cp.2014.1086

8. W.F. Alfiah, Rancang bangun sistem penjejak matahari sumbu tunggal berbasis arduino mega 2560. [Design and construction single axis solar tracking system based on arduino mega 2560]. [Undergraduate Thesis]. Teknik Fisika, Institut Teknologi Sepuluh Nopember, Surabaya, Indonesia (2015). [in Bahasa Indonesia]. p. 49. http://digilib.its.ac.id/ITS-NonDegree-24102150001230/38079 
9. H.E. Santoso, Rancang bangun solar tracking system menggunakan kontrol pid pada sumbu azimuth. [Design and construction single axis azimuth solar tracking system using pid control]. [Undergraduate Thesis]. Teknik Fisika, Institut Teknologi Sepuluh Nopember, Surabaya, Indonesia (2014). [in Bahasa Indonesia]. p. 50. http://digilib.its.ac.id/ITS-NonDegree-24102150001258/38987

10. I. Abadi, A. Musyafa, A. Soeprijanto, Int. Rev. Electr. Eng., 10,3:390-398(2015). https://doi.org/10.15866/iree.v10i3.6090

11. I. Abadi, A. Musyafa, A. Soeprijanto, Int. Rev. Model. Simulations, 8:640652(2015) https://doi.org/10.15866/iremos.v8i6.7907

12. I. Abadi, K. A. Permatasari, ARPN J. Eng. Appl. Sci., 13,3:835-845(2018). https://www.researchgate.net/publication/323470425_Pitch_and_yaw_angle_control _designin_solar_panel_system_using_PSO-Fuzzy_method 